\title{
Revisiting the university front
}

\author{
Grahame Lock $\cdot$ Chris Lorenz
}

Published online: 7 July 2007

(C) Springer Science+Business Media B.V. 2007

\begin{abstract}
The article argues that the most important trends in the recent metamorphosis of higher education, especially of university teaching and research, cannot be understood without placing them in the context of general developments in political life. Both processes reveal alarming features and there is a link between them. In recent decades a religion has established its dominance in the public policy field. Its dogmas are called "liberalization", "economic man", "individual preference", "the free market", "competition" and "efficiency". The consequences of the progressive imposition of this doctrine on the universities - including on the relation between teaching and research — are well documented but not always well understood. It is argued that the "commercialization" of higher education and research means in reality their hyper-bureaucratization, via the imposition of so-called evaluation, assessment and accreditation schemes, the latest avatars of the managerialist ideology. Might the final result be the disintegration of the university as an institution?
\end{abstract}

Keywords Postdemocracy · Public function of the university · Governance · Knowledge society $\cdot$ Research university $\cdot$ Managerialism $\cdot$ Academic audit . Quality control

Cf. Lorenz (1993). This essay is entitled, in English translation, "All quiet on the university front". The present piece takes up the story again.

G. Lock $(\bowtie)$

Radboud University, Thomas van Aquinostraat 5, Postbus 9108, 6500 HK Nijmegen, The Netherlands e-mail: g.lock@fm.ru.nl

C. Lorenz

Faculty of Arts, Department of History, Free University Amsterdam, De Boelelaan 1105, $1081 \mathrm{HV}$ Amsterdam, The Netherlands

e-mail: cfg.lorenz@let.vu.nl 


\section{Introduction}

The most important trends in the recent metamorphosis of higher education, especially of university teaching and research, cannot be understood without placing them in the context of general developments in political life. Both processes reveal alarming features and there is a link between them. That is the hypothesis proposed in the present article. In this connexion our discussion considers successively the topics of postdemocracy, liberalization, the fate of the public domain, the theology of "quality, efficiency and enterprise" and governance-versus-government. Turning more specifically to higher education, it looks at the issues of the university as an economic institution, the knowledge economy, the research university, audit, assessment, accreditation and accountability and finally the university's chances for survival.

It is no secret that perplexity and anguish reign in the once proud and confident academic community. The result of recent reforms in the university, writes the Dutch scientist and publicist André Klukhuhn, reflecting something of the new mood, is a "complete reversal in the vision of what a university is" (Klukhuhn 2002, p. 4). The historian Conrad (Earl) Russell remarked some time ago that "almost everything academics are now asked to do, most of them believe to be wrong", a striking formulation (Russell 1992, p. 109). Bruce Charlton concludes that the intellectual centre of gravity in society "will surely move outside the universities" (Charlton 2000, p. 3). Such comments are becoming increasingly common-though the educational world also abounds in enthusiastic reformers.

This article concerns general tendencies. It does not attempt to take account of the numberless local situations in which these tendencies are more or less-but always confusedly-reflected, nor of the diverse and often valiant attempts made in this or that institution to defend, to promote and to revitalize in daily practice (but in sometimes equivocal and even chaotic conditions) the idea of the university. Life, and university politics in particular, are always complex, tangled and paradoxical affairs. Our aim is to assay some salient findings concerning the public function of the universities and to make suggestions as to causes and consequences of the above-mentioned trends.

\section{Postdemocracy and the public sphere}

By now it is a commonplace to note that the great wave of ideological fashion in public policy—call it "commercialization", "privatization", "marketization", "liberalization" or whatever you like- has also swept across the higher education and research sectors, with far-reaching consequences. Indeed, it looks as if we shall be stuck with it for a good while yet. Still, we (the academics) must try to understand it, in order better to determine where our duty now lies. The fashion of which we are speaking standardly presents itself in general terms as an application of so-called "rational" methods to social problems. In fact it is more like a religion. ${ }^{1}$ Michael Power writes that since the mid-1980s a new theology of "quality, efficiency and enterprise" has emerged in higher education (Power 1999, p.98). This theology now rules the roost in the rest of the public sector too. It has its high (and

\footnotetext{
${ }^{1}$ See Legendre (1988, p. 63): "We need to place management in the perspective of the great religious schemes of mankind, schemes without which the modern version of dogmatic practices, especially those centering around the dual names of State and Law, is not really thinkable, by which I mean comprehensible from the anthropological point of view."
} 
local parish) priests, its rituals, its learned as well as vulgar jargon, and an ever-growing army of ecclesiastical administrators, called New Public Managers. Its dogmas force social reality into a straitjacket, severely distorting it, sometimes beyond recognition. But behind the religious structures lie political and economic power. ${ }^{2}$

The principal categories of this dogmatic system are well known. Let us name some more of them: aside of course from "liberalization", also "economic man", "individual preference", "the free market" and "competition", as well "accountability", "transparency", "good governance" and much besides. The dogma is not a subtle one. But peu importe: its categories are enjoined by compelling interests. What are the consequences of its imposition? Brian Barry writes: "(...) in a society where the assumption of the sovereignty of the market and of consumer preference is widespread, we may expect to find that universities, most of which depend on public funding, teach views and employ persons of a kind acceptable to those who pay the taxes." (Barry 1965, p.80) The new and improved version of this model is that the state, instead of itself "representing" such preferences, hands the universities over, lock, stock and barrel, to the so-called free market and to the laws of consumer demand.

It is, roughly, this improved model which the university reforms now in course are intended to implement. The details are of course terribly complex. There are counterproposals and compromise suggestions. The transformation process is far from complete. But its logic is rather simple. The reformers have, it is true, run up against various obstacles in the implementation of their plans. For many, perhaps most academics - or at least, academics of the generation which grew up in the old university-are themselves not adepts of the reform religion, certainly not in regard to their own institution and to their own function. They resist. This resistance is countered by the introduction of "scientific" control systems like New Public Management, which aim, via the systematic use of stick and carrot, at bringing the academics "into line". Meanwhile, the younger generations of university employees - they are ceasing, according to some commentators, to be unambiguously identifiable as "academics" - will be socialized in the new system. They will know nothing else.

Our universities are indeed being transformed. Some analysts prefer to say that they are being killed off. In Britain, Mary Evans of the University of Kent has published an essay with the title Killing Thinking: The Death of the Universities (Evans 2004). The Oxford professor of Sanskrit, Richard Gombrich, has written of the "murder of a profession", the academic profession (Gombrich 2000). In France, Pierre Jourde of the University of Grenoble has argued that "the French university system is dead" (Jourde 2003). In Canada, Bill Readings published an analysis of The University in Ruins (Readings 1996). Christian Galan has argued that the Japanese universities died in 2004 (Galan 2006). Similar conclusions have been drawn in respect of the Spanish, Italian, German and Polish universities among others. ${ }^{3}$

What is going on? How should we understand these claims? And what does it all mean for the theme of the public task of the university? The hypothesis presented in the present article is that the dramatic transformation of the universities is, globally speaking, one

\footnotetext{
2 And, we should add, though it is not directly our topic here, legal power. Ugo Mattei for example has written, in respect of post-Cold War developments in this field, that "the years following the Second World War have shown a dramatic change in the pattern of world hegemony in the law". He has offered a detailed specification of the elements of this change (Mattei 2003, p. 384).

3 A list of documentary links to critical studies of the universities of various lands can be found at the website http://fs-morente.filos.ucm.es/debate/inicio.htm. The different situations are in constant evolution.
} 
expression among diverse others of the general social and political trend referred to above, which affects the whole of the public sector. So it is also a symptom of something much deeper. Let us turn our attention for a few moments to this general trend. We are obliged by limited space to restrict ourselves to a schematic presentation. There are many qualifications and nuances to be added. But it may already be noted that a key notion for present purposes is that of postdemocracy.

A few years ago, the Russian philosopher Alexander Zinoviev remarked that "with the collapse of Soviet communism, humanity entered the era of postcommunism". We should add, he wrote, "that humanity has also entered the postdemocratic era" (Zinoviev 1999). What could justify such a bold claim? Colin Crouch, in his study of Postdemocracy (Crouch 2004) as well as in other publications claims that the "democratic moment" has passed. The meaning of postdemocracy, he notes, is a society in which the institutions that we always associated with democracy remain in place, but where the heart of the whole thing has somehow been removed, because the forces within society that make democracy work are undermined. Postdemocracy is then the "shift of power out of the whole [political] system towards private concentrations of global wealth" (Crouch 2005).

It is not of course that this phenomenon is in itself new: it is the degree of its dominance that changes everything. What has changed? Alan Scott usefully summarizes the four pillars of postdemocracy as, first, the "disembedding" of political elites, which are increasingly able to bypass control by the mass of the citizens; second, the "trivialization of politics", expressed in the latter's subordination to technical, managerial modes of decision-making; third, the imposition of "rituals of verification", which make use of formalized target-setting instruments like "mission statements", "organizational goals" and the like, as well as (essentially artificial) procedures of auditing, evaluation and accreditation; and fourth, an ever-growing permeability of the line between the public sphere and the private sphere (Scott 2005). If something like this describes the turn which western society is taking, what are the consequences for the public sphere?

Ross McKibbin puts it this way: the model of market-managerialism has largely destroyed all alternatives, traditional and untraditional, to its supremacy. And its most powerful weapon has been its vocabulary. Our students are now clients, our patients and passengers customers. It is a language, he remarks, "which was first devised in business schools, then broke into government and now infests all institutions." The language might itself be laughable, but it is now the shared language of those who command-and is imposed on those whom they command. It has, he adds, been destructive of the public sphere, helping to legitimate policies that constitute an attack on this sphere and on the idea of democratic citizenship as well as "turning citizens into supplicants" (McKibbin 2006).

Indeed, the very distinction between private and public has come under sustained pressure in the last decades. This crucial distinction is now under assault in what Paul Hoggett, in an essay on "Why public is not the same as private", calls the neo-liberal discourse of government (Hoggett 2003). But the name is less important than the reality. Sheila Marsh and Marion Macalpine recall that, on the practical front, we have in the last years seen public services of all kinds, like education and research, but also health care, energy, water and sanitation, coming under private control by various stratagems, including direct privatization, cuts in public spending and structural adjustment policies. The administrative tool by which existing public services are "brought into line" in readiness for these processes is managerialism - a special ideological approach to management "which increases both direct and indirect methods of control in order to enhance productivity, increase profit and/or reduce costs" (Marsh and Macalpine 2002, pp. 2-6). High manageralism, its sophisticated variant, attempts to achieve these ends by means of 
"ever-extending audit and performance management" of all workers at the metaphorical coal-face-whether coal-miners, policemen, judges, doctors, teachers or university professors and researchers (Marsh and Macalpine 2002, p. 1).

In the case of the universities there is, it is true, an important complication. It may be pointed out that there are private universities of great distinction. But these institutions, though legally private, pursue universal-educational and scientific-goals, goals of eminently public significance. The key reason why they are able freely to pursue such goals typically lies in their abundant financial endowments, which make it unnecessary for them to follow ordinary "private" market or commercial logic. This advantage is however not shared by the overwhelming majority of private or privatized institutions. Indeed, the difficulties now being encountered by what are perhaps Europe's best universities, Oxford and Cambridge, are rooted in the fact that while some of their colleges are financially fairly well endowed, the universities themselves are not. Thus they too are now beginning to suffer from the well-known "double whammy" of commercialization pressures and hyperbureaucratization.

However that may be: from the moment that a public institution or utility is "privatized", the logic of its operation is radically modified-and in a much-criticized direction (Leys 2003). This modification is however legitimated by a reference to the ideology of "public sector reform". This in essence propagates the notion that the role of government is to make policy and to fund services and programmes-but not to deliver such services (Hoggett 2003). But why should government not do the work of delivery? Because, it is suggested and endlessly repeated, the government as a monopolist is not as "efficient" as the private sector. It is astonishing but true: a quite unproven, indeed perfectly dogmatic notion has been widely accepted, to the effect that devolution of public services to the private sector means efficiency and "bureaucracy-busting". In reality, there is nothing as bureaucratic, in the noisome sense, as the present-day privatized sector. We shall indeed shortly see, when we consider higher education and research more closely, that their own forced insertion into the world of "market forces" has resulted in levels of bureaucratization previously unthinkable and hugely prodigal of public funds.

Worse yet: in reality it is by no means the case that there is a clear division of functions between policy-making and delivery, with at least the policy-making role safely in public hands. On the contrary, the private sector is now itself heavily, ever more heavily, involved de facto in policy-making - on the basis, of course, not of any criterion of the public good but of its own private ends.

\section{Governance versus government}

This far-reaching transformation in social decision-making structures is often called the "replacement of government by governance". How this process works is not difficult to understand, nor is it hard to penetrate the political, or perhaps better, the anti-political dogma which lies behind it. The general character of this trend has been well described by John Brown (Brown 2001). The essence of his account is that at each level—of urban governance, of national governance, of European governance and of global governancethe term "governance" refers to (new) modes of managing public affairs in which an appeal is made to the active intervention of the "stakeholders of civil society", with a parallel reduction in the role of properly political institutions. 
That the "governance way" constitutes a challenge not just to constitutional government but to democracy-as-we-know-it is not an abstruse philosophical imputation. It is a very real prospect. The European Union is, as we know, an uncontested world leader in the promotion of international governance structures. In 2001, inspired by the then President of the Commission, Romano Prodi, the European Commission published its White Paper on European Governance. The avowed aim of the White Paper was to establish "more democratic" forms of governance at all levels-global, European, national, regional and local (see Lock 2006).

What do these "more democratic" forms come to in practice? Mr Prodi has explained that "the challenge of democratic accountability faces Europe too". It is clear, he adds, "that representative democracy and the European institutional system as it has existed over the last half century are no longer meeting the aspirations of our citizens. They want $a$ much more participatory democracy, one that gives them a real say in shaping their future" (our emphasis, GL and CL; Prodi 2000, p. 5). The message is explicitly and perspicuously formulated: the old way, the way of "representative democracy", is no longer obviously valid. It must be replaced or supplemented by a new way, which Prodi and the White Paper call the "governance" way (cf. Supiot 2005, pp. 247-50).

Prodi's view of what the European Union means and of the direction in which it should be going is not the only view in European circles. But it is an influential view and, more importantly, is already in process of implementation. Moreover, with regard to implementation, as the above-mentioned White Paper itself insists, the "governance way" does not require that the "flexibilization" of policy-making always be imposed from above. There are myriad ways of proceeding.

\section{Postdemocracy and the universities: The Bologna process}

It is therefore not surprising, nor is it without significance, that the major policy initiative of recent years in the higher education field, known under the name of the Bologna Process, was initiated not by the European Union but rather by the 1999 Bologna Declaration, a "statement of intent" signed by 29 Ministers of Education and other representatives from EU and non-EU lands. (There are meanwhile 45 signatory states.)

In truth, the Bologna Process did not begin with the Bologna Declaration, nor is it limited to what was agreed at Bologna in 1999. We should note in this connexion not only other meetings and declarations (Sorbonne in 1998, Prague in 2001 and Berlin in 2003) but especially the European Commission's 1991 Memorandum on Higher Education in the European Community (see Tomusk 2006). This memorandum, as the European University Association notes, "refers to student mobility; cooperation between institutions; Europe in the curriculum; the central importance of language; the training of teachers; recognition of qualifications and periods of study; the international role of higher education; information and policy analysis; dialogue with the higher education sector"-all themes later taken up and exploited in the Bologna Declaration (EAIE 1992, p. 68, fn. 3).

This Declaration, together with the reforms consequent on it, is itself remarkable for more than one reason. First, the manner of imposition of these reforms. The 1999 meeting of ministers imposed no obligations on governments. Nothing in the Declaration with which it closed laid a requirement on states to implement any of the items contained in it. This point is well made by Hauke Brunkhorst in a recent article (Brunkhorst 2006), in which he argues that the national governments-and more especially the education ministries - made use of Bologna to play a familiar political game. In order to promote their 
own reform plans, they initiated the joint Bologna Process which, it was then suggested, required them to implement reforms of just this type (cf. Balzer and Martens 2004). Thus, any criticism of the content of these invasive plans would have to be addressed not to them but to "Europe" - for at the national level, it was suggested, little room for manoeuvre any longer existed.

Now the most extensive mutations in university organization in decades could be introduced with barely a reference to a sovereign decision-making organ. At best, the national parliaments were given the subordinate task of ratifying what the apparently unstoppable machinery of European harmonization required. Brunkhorst writes: "The united executive powers of Europe and their 'private-public' partners thus significantly extended their transnational class ascendancy, aggrandized their possibilities of action beyond any juridical limits and attributed to themselves previously undreamed-of prerogatives" (Brunkhorst 2006, p. 21). In a similar vein, it has been remarked that the Bologna Process is an example of a specifically neo-liberal way of governing. No longer is such governing done via legislation, but rather by various techniques of persuasion and tactics of manipulation. Thus the higher education reforms are marketed and sold as a fait accompli (Fejes 2005). It remains only to "implement" them-and their endless follow-ups.

That was the first point. The second point concerns the content of the Bologna-inspired reforms. These translate the principal dogmas of the managerialist cult. All of the main themes invoked in the statement of intent are couched in managerialese: the "knowledge society" (see below), the imperatives of "employability", "mobility" and "lifelong learning" (intended to appeal to a floating population whose security of employment has been continuously degraded) as well as "quality assurance". This last notion, as we shall soon see, has little to do with any kind of real-life quality but is an operationalization of the managerialist notion of "accountability to stakeholders", a notion institutionalized in everexpanding (and ever more profligate) audit, evaluation and accreditation procedures (Charlton 2001). As Lee Harvey notes, accreditation is neither neutral nor benign; it is not apolitical. It is fundamentally about a shift of power, but a shift "concealed behind a new public management ideology cloaked in consumerist demand and European conformity" (Harvey 2003, p. 1). Indeed, it has been bluntly suggested that the ultimate function of what is called accreditation must be to serve the most influential of the so-called stakeholders-in brief, to open higher education and research up to the "voracity of capital" (Alonso 2003, p. 1).

In any case, the logic of the Bologna Declaration seems clear: if not immediately, then one day something like the GATS (General Agreement on Trade in Services) rules are to be applied to the whole field of education, including the universities. GATS (see especially its article 15) threatens an end to the public financing of education. It describes subsidies as having "distorting effects on the services trade". Any public education system will, unless it is specifically excluded, fall under the GATS ban. This arguably means that "the objective of GATS is the pure and simple dismantling of public education" as a competitor with so-called "advantages" (thanks to public financing) over any "educational services" which may be put on the market by private companies (Alonso 2003). Although in the short run the European Commission has excluded education from the mainmise of GATS and the World Trade Organization, this exclusion, it is predicted, must sooner or later fall prey to the logic of the European Union's own increasingly neo-liberal creed. Quoting Alonso once again: "In the EU, the European Space of Higher Education (ESHE) is being developed in evident relation both to ... GATS (as a form of stepwise application of this agreement, to be completed by 2010) and to the objectives set by the European Council in Lisbon in 2000" (Alonso 2003, p. 3). These were to promote a "knowledge economy, the 
most competitive and dynamic in the world, capable of creating durable economic growth".

This notion of the "knowledge economy" is another reference now haunting debate on the function and future of the universities. It expresses yet another facet of the same ideology. As opposed to what the spin suggests, the notion of the knowledge economy does not at root mean the restructuring of the economy on the basis of scientific knowledge. On the contrary, it means that knowledge production is to be "economized": homo academicus is now to be modelled after homo economicus (Lorenz 2000, 2006a, 2006b).

The Bologna Process, in sum, reflects an obsession with the university understood as above all an economic institution. For instance, the pan-European substitution (in the absence of any substantial public debate) of existing university degree structures by a (more or less) uniform Bachelor-Master model has an economic rationale; and the choice of this scheme, rather than a continental European model, probably has to do with the perceived global economic "success" of UK higher education. The possibility that this exceptional success might be explained by the exceptional global position of the English language rather than by the formal structure of British educational institutions was not seriously considered. Indeed, the language question in European higher education is hardly ever discussed at policy level. Our hunch is that this is due to the fact that the linguistic domain is one which is particularly resistant to policy-making as such-and that policymakers do not like that idea.

To repeat the point: all of the relevant European declarations and plans are premised on a fundamentally economic view of education, treating the universities in particular primarily in terms of their function for the European economy and thus as providers of marketable commodities. The primary objective of these plans is the transformation of a great number of very diverse national systems of higher education into a single competitive European "educational market". How this objective is to be realized in practice is far less clear, especially because the national governments remain responsible for the implementation of the plans. By all accounts the EU is already facing serious problems in this connexion.

\section{The research university}

Most leading European universities are de facto heavily involved in extensive research activity, much of which is of great social utility, though in strikingly diverse senses of that term. In today's world the term "research university" is often used to denote such institutions. Yet there are problems involved in this appellation.

First: the very notion of "research" is of late date. It carries specific political connotations. It emerged in the German university world of the 19th century, under the inspiration of Wilhelm von Humboldt (see O'Boyle 1983). Research, in contrast to the "scholarship" which had preceded it, put the emphasis on professional specialization. In that sense it was the pendant to the ever more extensive division of labour characteristic of developing industrial societies. But in Humboldt's version it remained a "handicraft" type of specialization. Teaching and research were linked in an individual brain. The universities thus remained a "pre-industrial" enclave in a wider, partly more modern-but at the political level not yet fully modernized-society. Yet the industrial world soon made its inroads into the university, the great example being the role of the newly-introduced doctorate, whose popularity was closely linked with the needs of the burgeoning German chemical industry in the 1890s. This German model was subsequently introduced into the 
United States, in a sometimes forced combination with the principle of liberal learning typical of the English system. In England, by contrast, the German example was long resisted.

Present-day European universities have retained some of the elements of the German system, though these have everywhere been extensively modified in function of the changing role of the university in society. Thus, in a movement mimicking developments in the industrial and indeed post-industrial world, individual research - the ideal-type being that of the learned professor in constant quest of new knowledge in his own special fieldis being phased out and substituted by the "research programme", a collective effort in which each member is in principle interchangeable and expendable (Lock 1989). The institution of the research programme in fact "Taylorizes" the researchers, transferring power from those in search of knowledge to the management strata which control the channelling of funds to the programmes in question. Better, we might say, the (old) Oxbridge way, where "research programmes" were unheard of-indeed, where academics did not do research but just read, discussed, reflected and wrote.

Second: among the contemporary universities, some have a much greater "research component" than others. Thus it is estimated that there are about 4,000 colleges and universities in the United States (far more than any other nation), but that fewer than around 100 of these are true research universities (Sample 2002). The real research universities may generate up to half of their funds from research activities. Thus they are regarded as "a vast storehouse of intellectual capital". That is what, today, "research" is increasingly about: finance. It costs a great deal of money, but it generates even more.

That is the theory. In practice, only certain disciplinary domains are even potential money-spinners. These are mainly the applied sciences, for example those with a pharmaceutical or biomedical or information-technological relevance. Other fields of research are thus threatened, in the new regime, with funding cuts or even with abolition. Indeed, many have already disappeared. Governments meanwhile have preferred to extend control of research activity by channelling an ever higher percentage of funding either through "independent" national bodies-which means independent of the universities, though not of pressure from the various powerful social "stakeholders", who can thus correct any tendency to "wasteful" use of funds-or through special-purpose research establishments, whose mission can be defined in advance by higher authority and whose employees can thus have no illusion that they enjoy a general freedom of enquiry.

If, in contrast, the role of a university is to provide a sphere in which genuinely critical thinking, investigation and debate can take place, it would follow that university research cannot take the form of a mere response to "societal demand", nor university teaching that of "textbook transmission". The integration of university teaching with research, as well as the demarcation line between university education and professional education, thus become more relevant than ever. Yet this critical function seems now to be structurally threatened. Many European governments are indeed legislating to regulate the labour contracts of their academic "employees" (for that is how academics are nowadays regarded and treated) in such a way as to require them to operate within teaching and research programmes (see above) whose very content must be approved by "higher" authority, typically the Dean of the Faculty. And the Dean will nowadays ever more often be an appointed official, the time-honoured system of election by the community of peers - the corps of professors-having been abolished by law. So we have a neat hierarchy of control in a normalized university. Mary Evans suggests that the audit and accreditation procedures applied to the British universities are taking them in something 
like this direction-encouraging the replacement of original and critical thought by the transmission of bowdlerized information (Evans 2004).

\section{Audit, assessment, accreditation and accountability}

Let us now turn to that often misunderstood phenomenon, the audit revolution. Since research pursued in the public universities involves the use of public funds and is properly a matter of public concern, one might be tempted to believe that the various nation-wide evaluation and assessment procedures introduced in recent years are to be welcomed as a contribution to the "transparency" and "accountability" of academia. But this would be a fundamental mistake. Like many other terms of the managerialist vocabulary, "transparency" and "accountability" do not bear the sense they seem to. They are technical terms whose meaning and significance is derived from audit ideology (see below).

Michael Power, author of The Audit Society: Rituals of Verification, argues that the purpose of the new evaluatory mechanisms and indicators introduced into university administration since the 1980 s may be to "bend a recalcitrant academia" to what the government deems to be the new reality (Power 1999). These mechanisms are by now a nearly universal phenomenon in European higher education. Many commentators, Power remarks, regard them as having created explicit pressures not only for switching to private research funding but also for separating research and teaching (Power 1999, p. 99). It is clear that such exercises are not neutral recording instruments. Michael J. McIntyre calls the audit culture "an emergent socio-anthropological phenomenon of formidable power". Its starting-point is that "accountability" means "strict conformity to objectives measurable within the system" and it thus equates success with measurable output, the relevant (or irrelevant) "measures" being determined in advance by exogenous interests (McIntyre 1999, p. 1).

But another problem now rears its head. It is that, given the historical and factual absence of any generally operative market mechanism in the public services sector, another principle has come to stand proxy for this missing mechanism. This alternative principle is drawn from New Public Management (NPM); see above. It makes use of a double criterion, of efficiency and accountability. Whereas the notion of practical action normally presupposes some substantive goal or goals, being efficient is simply defined as being costeffective. And being accountable_-as well, of course, as being "transparent" - just means, for institutions reformed on NPM lines, being able to control and document their costeffectiveness. Small wonder, therefore, that NPM in the former public sector, again including higher education, has manifested itself in the typical combination of (1) a continuous reduction in service levels; (2) a continuous reduction in the level and quality of employment, that is, de-professionalisation and job cuts; (3) ever rising prices for the consumers of the "services" in question.

Applied to higher education, the introduction of NPM has typically meant: (1) a continuous deterioration in the student-staff ratio, leading to ever rising work pressure on faculty members (and since NPM's interest in faculty members lies primarily in the cost of their labour, it is certain that this tendency will persist); (2) continuous pressure to reduce numbers of faculty members as well as the decomposition of the academic staff into a "core" and a "periphery" of part-time and untenured faculty; (3) constantly rising tuition fees for the students (Barry and Dent 2004, p. 13). 
So what stands proxy to "the market" is an extended set of managerial control procedures. These, as those who have experienced them know only too well, are immensely top-heavy and, in their ever more counter-productive operation, "penny wise and pound foolish". Thus the university is as a matter of fact very far from being an enterprise operating "on business lines". Yet, constantly aping business corporations, it has bowed to every successive management fad (Johnson et al. 2003). The immense transaction costs of the hyper-bureaucratic procedures thus introduced, which even an elementary understanding of economics would require to be taken into account, are systematically ignored (while simultaneously there is no end of talk about 'accountability'!) and are thus rendered 'invisible'. Some analysts ungenerously suggest that there is an all-too-simple reason for this: these transaction costs pay the New Public Managers' salaries.

For the rest, the principal goal of the quasi-market-oriented "public services" is costcutting, as the logic of efficiency indeed requires. This explains another feature of NPM in higher education: the permanent character of successive rounds of budget cuts and of money-saving reorganizations. Since no substantive goals lie behind this policy, every cut is just a stepping stone to the next.

The extended mode of the hegemony of instrumental rationality, alias efficiency, has been baptized by George Ritzer with the name "the McDonaldization of society" (Ritzer 1993). We should therefore not be surprised to find the European universities being transformed into entrepreneurial McUniversities. Features characteristic of this new type of institution include ever-growing managerial power, permanent structural reorganization, ever greater emphasis on the marketing of the institution (making use of tried-and-trusted Public Relations methods) and on the generation of finance from partnerships with business, the introduction of performance-related pay, the "rationalization" (and computerization) of administrative structures, together with all-round harmonization and standardization (Parker and Jary 1995, pp. 320-21). The phenomenon of ranking (of citations, journals, individual researchers, research groups, departments, universities etc.) is an integral part of this transformation (see, for a short history of university ranking, Brooks 2005).

The new university, as we know, strives for accountability. But the concept of accountability, as remarked above, is not an innocent or unproblematic one. As presently applied, it is not (as some might think) a response to a general, ethically innocuous demand that institutions as well as individuals with a function in such institutions should account for their policies and actions to the general public or to a professional body. On the contrary, it has a very specific and restricted meaning drawn from the internal system of managerialism (Charlton 2002). What is this meaning?

In principle, accountability, realized through audit reports, is a simple thing. For audit consists in its most elementary form in the checking of a left-hand column against a righthand column, in order to discover whether mistakes have been made or fraud committed. So everything depends on what is included in the left-hand column. In the case of universities, as of many other institutions, this left-hand column will standardly specify an "organizational mission" (mission statements are yet another tool in the managerialist repertoire) and provide a specific list of "quality indicators".

As Bruce Charlton and Peter Andras point out, the word "accountability" originally just meant having the duty to present auditable accounts. This is the technical managerial meaning of the term. The extension of the concepts of accountability and of audit to nonfinancial and indeed non-managerial matters-like "academic performance"—constitutes a later, not just managerial but managerialist, i.e., highly ideological application, or rather misapplication, of these instruments (Charlton and Andras 2002). 
The important point is that academic quality —of both teaching and research—is coming to be defined in terms of such auditable indicators. It is rather as if truth were to be defined as equivalent to particular values for blood pressure, heart rate, respiration and skin conductivity, as measured by a lie detector (polygraph). It is a rash justice system that would base its policy on such an equivalence. It is a rash education system that would base its policy on "audited quality".

To the extent that university teachers and researchers do not clearly grasp that one and the same term, "quality", can thus have two quite different, indeed directly contrary meanings, they may in their confusion tend to acquiesce in managerial reforms which they might otherwise resist. For example, an "academic production process" that cuts down the number of hours spent in discussion with students or that eliminates "costly" minority-interest courses will be of lower quality in the real sense but of higher quality in the managerialist sense: that is, more "efficient", "producing" graduates at a lower cost per item.

\section{Do the universities have a future?}

The inspiration of those who stand opposed to the reforms now being visited on the universities by national governments and by European policy-makers-opposed not so much to particular details as to the whole trend of these reforms-does not for the most part lie (as is often claimed) in a nostalgic attachment to an obsolete or unrealistic idea of the institution. It is not that the critics just prefer the old university to the new one. On the contrary, they believe that, whereas the old university has been rather successful, and over a rather long period, the new university will simply not work, not even in its own terms. It will not work, it is claimed, for at least two reasons.

First, though basing itself on the subordination of all values to ultimately economic goals, the new university is in fact parasitic on a residue of non-economic academic values, which however it cannot reproduce-whose reproduction it in fact tends to undermine. As the economic gleichschaltung runs its course, the university will find itself left high and dry and, if nothing is done in the meanwhile to reverse the process, could disintegrate. Martins argues that, in fine, "the Age of Universities (late 11th century-early 21st century) in the West may be drawing to a close anyway". There may in future, he adds, still be "academics" of sorts, claiming lineal descent from the scholars of yesteryear, but "no longer scholars-in-universities, in contradistinction to academic managers, or skills managers" - in fact, no longer universities at all, "except, for a bit longer, in name" (Martins 2004, p. 48).

Second, this tendency to disintegration is likely to be paralleled by the hyper-bureaucratization consequent on the imposition of the logic of managerialist audit. This logic, by its very nature, knows no bounds or limits. There is always, whatever institution or activity may be summoned to "render its account" (a faculty, a degree course, a research programme etc.), yet another potential item to add to the auditable list, more implicit knowledge to be clumsily transformed into a list of peremptory "indicators", another control mechanism - call it, say, "accreditation" - to be added to the bulging toolbox of supervision. Michael Power remarks that "some societies have tried to institutionalize checking on a grand scale. These systems have slowly crumbled because of the weight of their information demands, the senseless allocation of scarce resources to surveillance activities and the sheer human exhaustion of existing under such conditions" (Power 1999, p. 2). It is as if society had fallen prey to a mysterious and enervating sickness whose 
principal symptom is a neurotic demand for checks and double checks without end. Institutional self-strangulation is a predictable result.

The conclusion must surely be that the present general line of university-teaching and research-reform is an ill-starred one. Better, it seems, never to have gone down this path. But the path is now a European, indeed a Western highway. In this unhappy situation, a first - if not, to be sure, the only — task of academics and scholars must be to keep alive an idea of the university and of its public function and to transmit that idea to the next generation. This idea cannot be a merely historical one, but must take specific account of the challenge of our day: to defend a cogent alternative to the currently dominant model. So our first responsibility must lie, sit venia verbo, in speaking some uncomfortable truths to power. $^{4}$

\section{References}

Alonso, C. S. (2003). European union: The threat to education. IV Online magazine, November. Retrieved October 11, 2006, from www.internationalviewpoint.org/spip.php?article120.

Balzer, C., \& Martens, K. (2004). International higher education and the Bologna process: What part does the European Commission play? (Paper presented to the epsNet 2004 Plenary Conference on Political science after the EU enlargement, Prague, June 18-19).

Barry, B. (1965). Political argument. London: Routledge.

Barry, J., \& Dent, M. (2004). New public management and the professions in the UK. Reconfiguring control? In M. Dent, J. Chandler \& J. Berry (Eds.), Questioning the new public management (pp. 720). Aldershot: Ashgate.

Brooks, R. L. (2005). Measuring university quality. The Review of Higher Education, 29(1), 1-21.

Brown, J. (2001). De la gouvernance ou la constitution politique du néo-libéralisme. Retrieved October 11, 2006, from http://www.attac.org/fra/list/doc/brown.htm.

Brunkhorst, H. (2006). So wird Sachzwang gebaut. Die Tageszeitung, Berlin, August 12.

Charlton, B. (2000). Shape of things coming. Oxford Magazine, 182, 1-3.

Charlton, B. (2001). If not quality assurance, then what? Spiked Culture. Retrieved October 11, 2006, from http://www.spiked-online.com/Articles/00000002D20D.htm.

Charlton, B. (2002). Audit, accountability, quality and all that: The growth of managerial technologies in UK Universities. Retrieved October 11, 2006, from http://www.hedweb.com/bgcharlton/audit.html.

Charlton, B., \& Andras, P. (2002). Auditing as a tool of public policy. The misuse of quality assurance techniques in the UK university expansion. European Political Science, 2, 24-35.

Crouch, C. (2004). Postdemocracy. London: Polity Press.

Crouch, C. (2005). Coping with Post-democracy (POWER Inquiry Witness Session, Manchester, 28 April). Retrieved October 11, 2006, at http://www.fabian-society.org.uk/net.asp.

EAIE (European Association for International Education) (1992). International education in Europe: A professional view on the Memorandum on Higher Education in the European Community. Amsterdam: EAIE.

Evans, M. (2004). Killing thinking: The death of the universities. London: Continuum.

Fejes, A. (2005). The Bologna process - Governing higher education in Europe through standardisation. (Paper presented to the third conference on Knowledge and Politics: The Bologna process and the shaping of the future knowledge societies, University of Bergen, Norway, May 18-20).

Galan, C. (2006). La libéralisation de l'enseignement supérieur au Japon. (Paper presented to the ARESER Colloquium L'Université a-t-elle encore un avenir en Europe? Paris, February 11).

Gombrich, R. (2000). British higher education policy in the last twenty years: The murder of a profession. Retrieved October 11, 2006, from http://www.ucl.ac.uk/ ucgadkw/position/gombrich/uk-highereducation.html.

Harvey, L. (2003). The power of accreditation: Views of academics. (Paper presented to the ENQA Workshop on Accreditation Models in Higher Education, November 12-15).

Hoggett, P. (2003). Why public is not the same as private. Retrieved October 11, 2006, from http:// www.ispso.org/Symposia/Boston/hoggett.htm, 2003.

\footnotetext{
${ }^{4}$ With thanks for support to the Leuven-Nijmegen Covenant (Radboud Universiteit Nijmegen and Katholieke Universiteit Leuven).
} 
Johnson, B., Kavanagh, P., \& Mattison, K. (2003). Steal this university: The rise of the corporate university and the academic labor movement. New York: Routledge.

Jourde, P. (2003). Ce qui tue l'Université française. Le Monde Diplomatique, September 2003.

Klukhuhn, A. (2002). Rather the poisoned chalice: On universities and the market. Retrieved October 11, 2006, from http://www.phys.uu.nl/ kritstud/eklukhuhn.htm.

Legendre, P. (1988). Le Désir politique de Dieu. Paris: Fayard.

Leys, C. (2003). Market-driven politics: Neoliberal democracy and the public interest. London: Verso.

Lock, G. (1989). The collectivisation of the Dutch universities. Minerva, 27(2-3), 157-176.

Lock, G. (2006). Watching out for 'governance': The nature and future of an illusion. Episteme. Revista de Epistemologia e Historia das Ciencias, ano VI, nos. 15-16-17, 19-37.

Lorenz, C. (1993). Van het universitair front geen nieuws. Baarn: AMBO.

Lorenz, C. (2000). The myth of the Dutch middle way. Wissenschaftsrecht, 33, 189-209.

Lorenz, C. (2006a). Dutch university governance and the Bologna Declaration. Oxford Magazine, 250, 4-6.

Lorenz, C. (2006b). Will the universities survive the European Integration? Higher education policies in the EU and in the Netherlands before and after the Bologna Declaration. Sociologia Internationalis, 1, 129.

Marsh, S., \& Macalpine, M. (2002). Perversity and absurdity in 'high managerialism'. (Paper presented to the Connecting Learning and Critique Conference, Cambridge.).

Martins, H. (2004). The marketisation of universities and some cultural contradictions of academic capitalism. Metacrítica, Revista de filosofia, 4, 2004; extended version retrieved October 11, 2006, from http://www.adelinotorres.com/sociologia.htm.

Mattei, U. (2003). A theory of imperial law. Indiana Journal of Global Legal Studies, 10(1), 383-448.

McIntyre, M. J. (1999). Audit, education and Goodhart's law: Or, taking rigidity seriously. Retrieved October 11, 2006, from http://www.atm.damtp.cam.ac.uk/people/mem/papers/LHCE/dilnot-analysis.html, 1999.

McKibbin, R. (2006). The destruction of the public sphere. London Review of Books, 28(1), 3-6.

O'Boyle, L. (1983). Learning for its own sake: The German university as a nineteenth-century model. Comparative Studies in Society and History, 25(1), 3-25.

Parker, M., \& Jary, D. (1995). The McUniversity: Organization, management and academic subjectivity. Organization, 2, 319-338.

Power, M. (1999). The audit society: Rituals of verification. Oxford: Oxford University Press.

Prodi, R. (2000). Speech to the Second COMECE Congress, Brussels.

Readings, B. (1996). The university in ruins. Cambridge, Mass.: Harvard University Press.

Ritzer, G. (1993). The McDonaldization of society. Thousand Oaks, CA: Pine Forge Press.

Russell, C. (1992). Academic freedom. London and New York: Routledge.

Sample, S. B. (2002). Address to the 23rd Army Science Conference, Orlando, Florida, December 2.

Scott, A. (2005). Governance: Multi-level or post-democratic? (Paper presented to the working group on Sub-national dilemmas in an age of multilevel governance, AMIDST, Amsterdam).

Supiot, A. (2005). Homo juridicus. Paris: Seuil.

Tomusk, V. (2006). Melancholy and power, knowledge and propaganda: Discussing the contribution of the Bologna process to higher education research. Retrieved October 11, 2006, from http://ugle.svf.uib.no/ svfweb1/filer/1303.pdf.

Zinoviev, A. (1999). Une guerre contre l'Europe, Le Monde, Paris, May 25. 